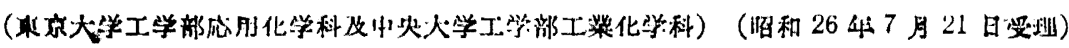

（4）熔成燐肥の蹠物組成亡构溶性について（第 2 報）

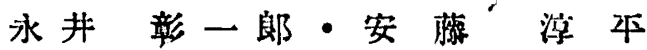

\section{1. 的}

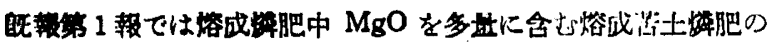

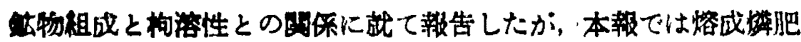
にカリ分が入つた场合の效喿化就て研究した絬果を瓶告する。從

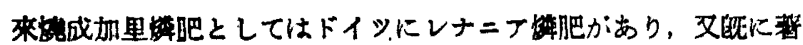

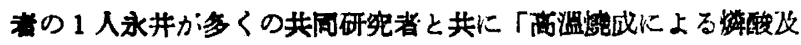

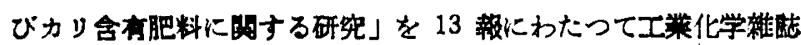
に無表1）しているか，これらは何れる燐鉣石，カリ鉣石改ひ石灰

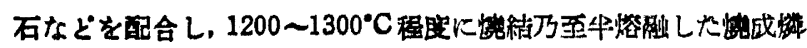

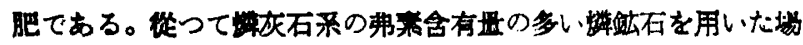

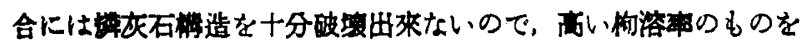
得られなかつだ2。

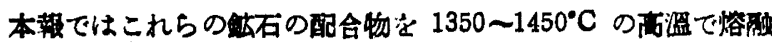

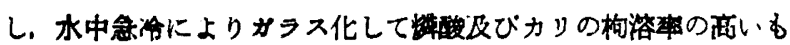
のを得，更にこれらの熔蜰物を急椧しないで自然放冷した场合に

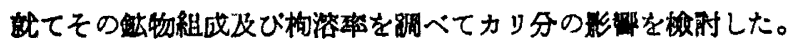

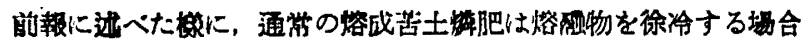

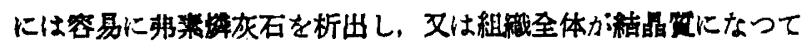

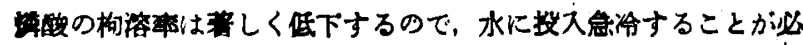

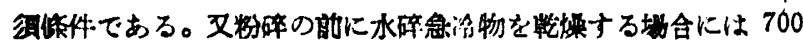

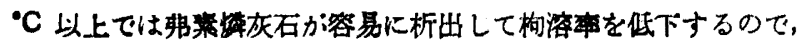

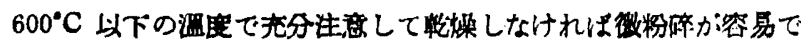

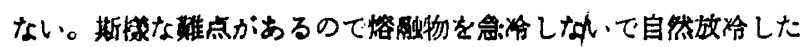

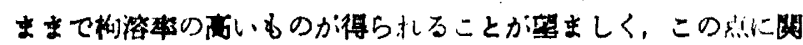
ナるカリの作用を特に道求したわけである。

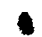

\section{2. 供試した試料及び容鎰方法}

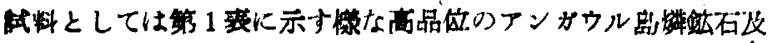

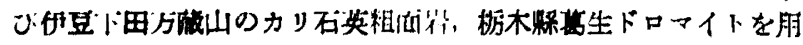

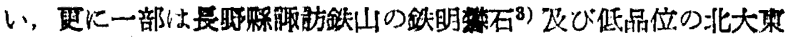

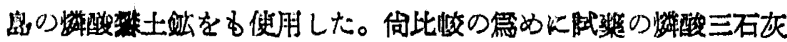
をる优用した。

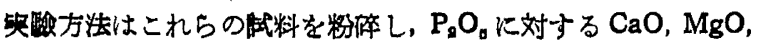
$\mathrm{K}_{2} \mathrm{O} ， \mathrm{SiO}_{3}$ などのモル比を造喽に配合を行い，その $30 \sim 40 \mathrm{~g}$ を

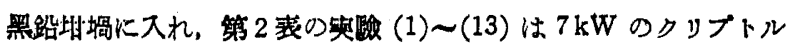

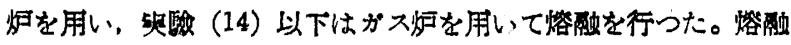
物は一部は水中に投入急冷し，他の一部はそのまま炉內に放证し

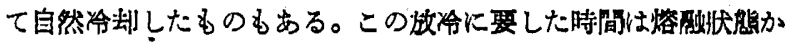
ら $600^{\circ} \mathrm{C}$ まて下るのにクリプトル炉の埸合は約 2 時蔺，がス炉の

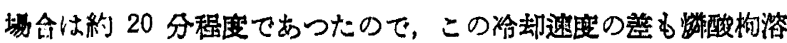

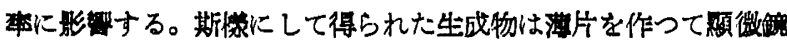

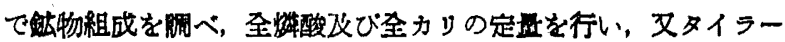

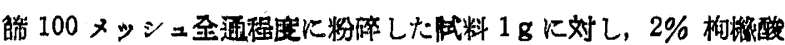

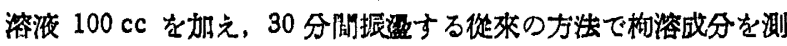
定した。

\section{3. 实騮結果とその考察}

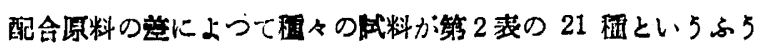

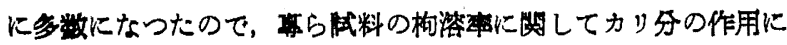
就て为寗した。

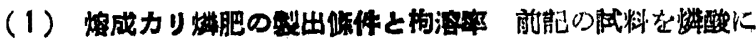

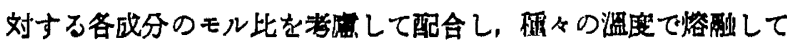
得た結果住第 2 装に一括して示した通りでめる。これらの中，央

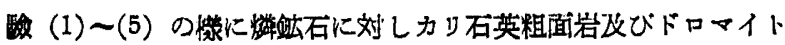

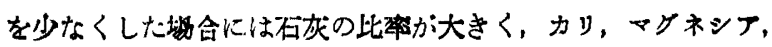

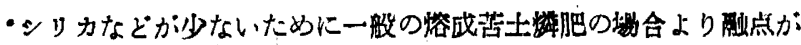

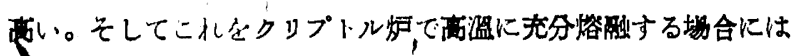

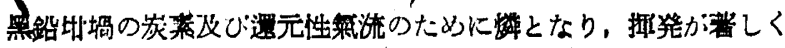

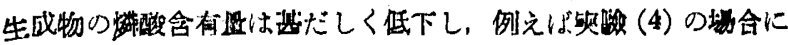
第 1 变 战料 0 成分 $(\%)$

\begin{tabular}{|c|c|c|c|c|c|c|c|c|c|c|}
\hline & 连地名 称 & Ig. 1088 & $\mathrm{SiO}_{2}$ & $\mathrm{Al}_{2} \mathrm{O}_{8}$ & $\mathrm{Fe}_{8} \mathrm{O}_{0}$ & $\mathrm{CaO}$ & $\mathrm{MgO}$ & $\mathrm{PaO}_{\mathrm{a}}$ & $\mathrm{K}_{2} \mathrm{O}$ & $\mathrm{SO}_{\mathrm{a}}$ \\
\hline (1) & 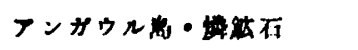 & 8.21 & 0.73 & \multicolumn{2}{|c|}{2.81} & 47.03 & - & 37,45 & - & - \\
\hline (2) & 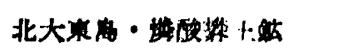 & 15.51 & 26.91 & 26.56 & 9.08 & 5.23 & - & 17.08 & - & - \\
\hline (3) & 伊五万做山・カリ不获粗面崶 & 1.92 & 71.45 & 13.66 & 2.33 & 0.72 & 0.33 & 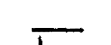 & 9.83 & $\mathrm{Na}_{2} \mathrm{O} 0.10$ \\
\hline (4) & 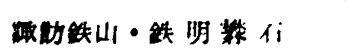 & 34.02 & 0.42 & 0.78 & 47.15 & 0.79 & 0.87 & & $8.29 l$ & 30.86 \\
\hline (5) & 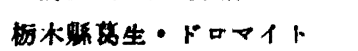 & 46.55 & 0.25 & \multicolumn{2}{|c|}{0.27} & 34.00 & 18.45 & & - & \\
\hline
\end{tabular}

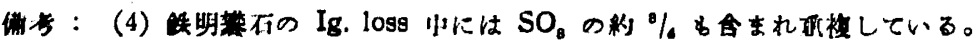

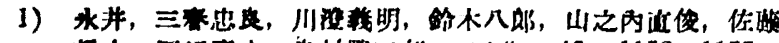

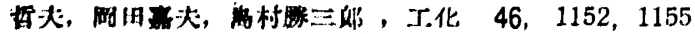
(1943) ; 50, 161 (1947) ; 51, 8, 9, 73, 86, 124, 127 (1948) ; 52, 127, 179, $287(1949) ; 53,50(1950)$.

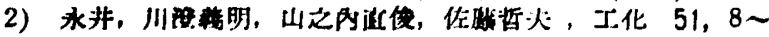
11, 73 75 (1948).

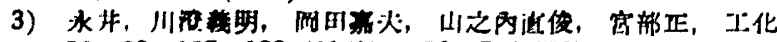
$52,83,127,133(1949) ; 53,7$ (1950)

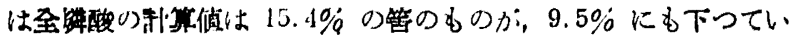

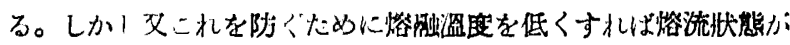
瑟くなつて急泠物在无分ガシス状然に保ら得なかつた。何れにし てもこれではよい絹果か得られなかつた。

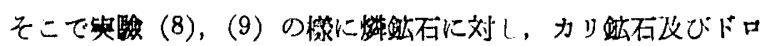

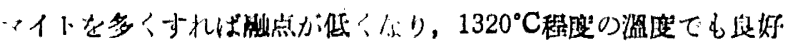




\begin{tabular}{|c|c|c|c|c|c|c|c|c|c|c|c|c|c|c|c|c|c|c|}
\hline \multirow{2}{*}{ 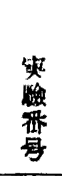 } & \multicolumn{4}{|c|}{ 脚 合 制 合 } & \multicolumn{5}{|c|}{$\mathrm{P}_{2} \mathrm{O}_{0} 1 \mathrm{MK}$ 対するモ几比 } & \multicolumn{3}{|c|}{ 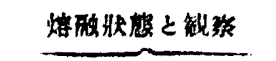 } & \multicolumn{3}{|c|}{ 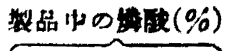 } & \multicolumn{3}{|c|}{ 紫品中のり $(\%)$} \\
\hline & 燐放 & カ & り跠 & F゙ロ & $\mathrm{K}_{9} \mathrm{O}$ & $\mathrm{MgO}$ & $\mathrm{CaO}$ & $\mathrm{SiO}_{2}$ & $\mathrm{Al}_{2} \mathrm{O}_{8}$ & 滑熙) & (分) & 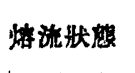 & 余溸 & 向海 & 勿视 & $\rightarrow$ & 构港 & 姁始 \\
\hline$\left\{\begin{array}{l}\text { No. } \\
1 \\
2\end{array}\right.$ & $\begin{array}{l}\text { アンガ } \\
\text { ウル10 } \\
\text { "I }\end{array}$ & 五 & $\begin{array}{l}\text { y石䓋 } 7 \\
\text { 面崇 } \\
\text { "I }\end{array}$ & $\begin{array}{l}7 \\
\prime \prime\end{array}$ & $\begin{array}{l}0.3 \\
\prime \prime\end{array}$ & $\begin{array}{l}1.2 \\
1.7\end{array}$ & $\begin{array}{l}4.8 \\
5.5\end{array}$ & $\begin{array}{l}3.2 \\
11\end{array}$ & $\begin{array}{l}0.4 \\
\prime \prime\end{array}$ & $\begin{array}{l}1380 \\
1420\end{array}$ & $\begin{array}{l}20 \\
\prime \prime\end{array}$ & 稍是 & $\begin{array}{l}15.8 \\
11.7\end{array}$ & $\begin{array}{l}9.05 \\
9.10\end{array}$ & $\begin{array}{l}57.3 \\
81.8\end{array}$ & $\begin{array}{l}3.01 \\
-\end{array}$ & 1.80 & $\begin{array}{r}59.9 \\
-\end{array}$ \\
\hline $\int 3$ & 10 & & 10 & 10 & 0.4 & 1.7 & 5.5 & 4.5 & 0.5 & 1370 & 20 & 䅌良 & 12.8 & 7.61 & 59.5 & 3.61 & 2.53 & 69.3 \\
\hline\{ & " & & $" \prime$ & $" \prime$ & " & " & $\prime \prime$ & "I & " & 1420 & " & 良 & 9.50 & 7.77 & 81.9 & - & 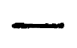 & 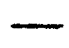 \\
\hline 5 & 10 & & 12 & 10 & 0.5 & 1.7 & 5.5 & 5.4 & 0.6 & 1450 & 10 & 战 & 10.8 & 8.54 & 79.3 & .20 & 2.86 & 65.5 \\
\hline 6 & 10 & & 15 & 10 & 0.6 & 1.7 & 5.5 & 6.8 & 0.8 & 1380 & 15 & 释是 & 11.9 & 8.82 & 74.3 & 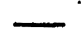 & - & 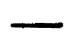 \\
\hline 7 & $\prime \prime$ & & " & 15 & " & 2.6 & 6.7 & $" \prime$ & " & 1320 & 20 & " & 10.8 & 7.69 & 71.2 & 4.18 & 2.84 & 68.0 \\
\hline 8 & " & & " & 17.2 & " & 3.0 & 7.1 & "I & "I & " & " & 放 & 10.5 & 8.45 & 80.6 & 3. 90 & 3. 48 & 89.1 \\
\hline 9 & " & & "I & 20 & $" \prime$ & 3.5 & 7.8 & "' & " & " & " & $\prime \prime$ & 10.1 & 9.84 & 97.5 & 3.65 & 3.32 & 91.0 \\
\hline 10 & "I & & " & "l & " & $\prime \prime$ & "I & " & "I & " & " & 放 冾 & " & 2.79 & 27.5 & " & 1.26 & 39.5 \\
\hline 117 & 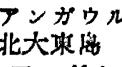 & $\begin{array}{r}\pi 5 \\
5\end{array}$ & 5 & 10 & 0.2 & 1.8 & 4.5 & 4.2 & 1.3 & 1320 & 20 & 良 & 12.01 & 0 & 60.0 & 2.13 & 1.65 & 77.6 \\
\hline 12 & $\begin{array}{l}\text { アンカ゚ウ } \\
\text { ル } 10\end{array}$ & & 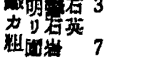 & 10 & 0.4 & 1.7 & 5.5 & 3.2 & $\begin{array}{l}\mathrm{Al}_{2} \mathrm{O}_{8}, 0.4 \\
\mathrm{Fe}_{9} \mathrm{O}_{8} 0.4\end{array}$ & 1360 & 30 & 食 & 16.3 & 9.56 & 58.7 & 3.03 & 2.81 & 92.2 \\
\hline 13 & " & カリ石引 & 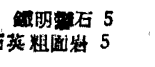 & 10 & 0.4 & " & $" \prime$ & 2.3 & $\begin{array}{l}\mathrm{Al}_{8} \mathrm{O}_{8} \mathrm{O} \\
\mathrm{Fe}_{2} \mathrm{O}_{8} \mathrm{O}\end{array}$ & 1340 & 50 & 稍 蚁 & 14.6 & 7.28 & 49.8 & 2.38 & 1.90 & 79.8 \\
\hline$l^{14}$ & $10 t$ & カリス & 石落粗闻岩7 & 77 & 0.3 & 1.2 & 4.8 & 3.2 & 0.4 & 1420 & 20 & 是 & 15.6 & 14.4 & 92.3 & 3.26 & 3.13 & 96.0 \\
\hline 15 & " & & " & $" \prime$ & $" \prime$ & $\prime \prime$ & $\prime \prime$ & $1 "$ & $\prime \prime$ & " & $" 1$ & " (放冷) & " & 7.73 & 49.6 & $\longrightarrow$ & - & - \\
\hline 16 & " & & " & 1.0 & $" \prime$ & 1.7 & 5.5 & $" \prime$ & " & 1430 & " & 量 & 14.1 & 13.8 & 97.8 & - & - & - \\
\hline 17 & " & & " & " . & $\prime \prime$ & $\prime \prime$ & $" \prime$ & $\prime \prime$ & "I & " & $" \prime$ & "I (放冷) & " & 9.12 & 64.8 & $\longrightarrow$ & $\longrightarrow$ & - \\
\hline 18 & 10 & & 16 & 16 & 0.6 & 2.7 & 6.8 & 7.2 & 0.8 & 1390 & 30 & 丧 & 10.6 & 9.55 & 94.0 & 4.26 & 3.99 & 93.7 \\
\hline$\{19$ & 11 & & " & $" \prime$ & " & $" \prime$ & $" \prime$ & $" \prime$ & " & " & " & $\prime \prime$ & " & 9.41 & 88.8 & $"$ & 3.99 & 93.7 \\
\hline 20 & 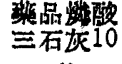 & & 20 & 20 & " & $" \prime$ & " & $" \prime$ & " & " & " & $" \prime$ & 11.2 & 1.0 & 98.4 & 4.72 & 4.65 & 98.5 \\
\hline 21 & $" 1$ & & " & " & " & $" \prime$ & !" & 6.7 & " & " & $"{ }^{\circ}$ & " (放冾) & $\prime \prime$ & 10.9 & 97.4 & $\prime \prime$ & 4.68 & 99.3 \\
\hline
\end{tabular}

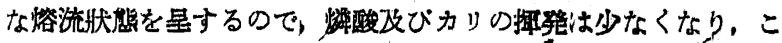

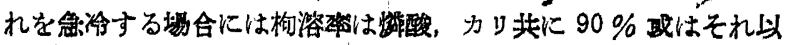
上の荡いものが得られる。しかしこの㙋合は生成物中の路酸含有

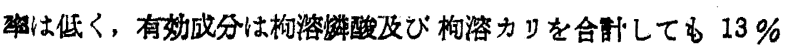
程度にしかならながった。

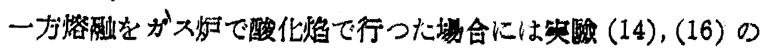

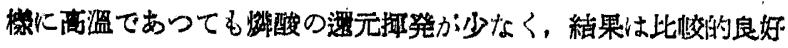

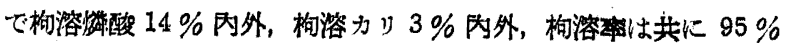

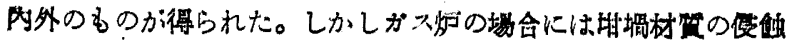

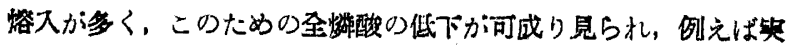

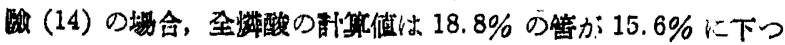

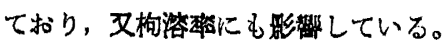

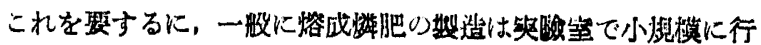

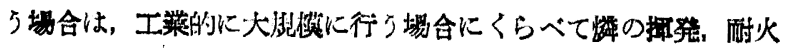

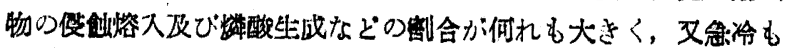

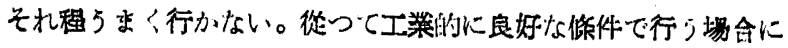

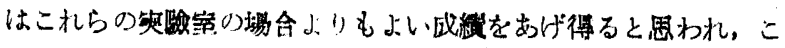

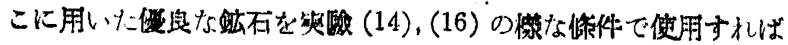

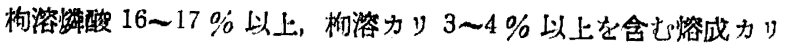

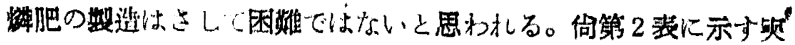

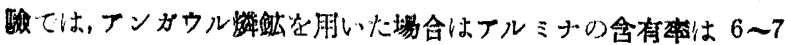

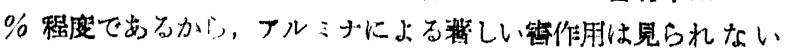

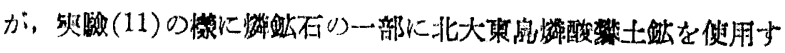

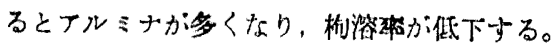

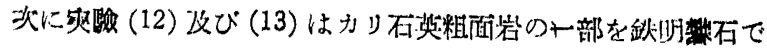

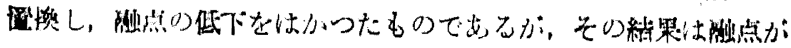

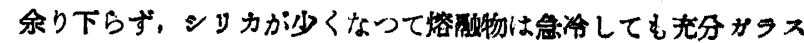
化しないため，构浴率却つて低くなつた。又これらの笑部に於

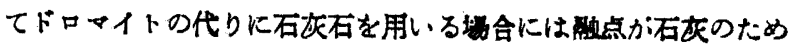

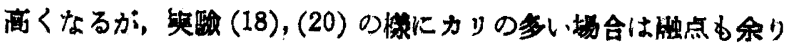

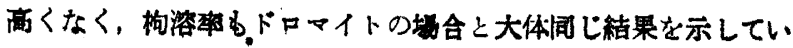
る。

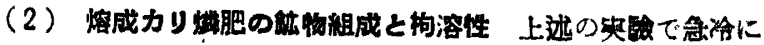

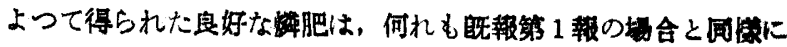

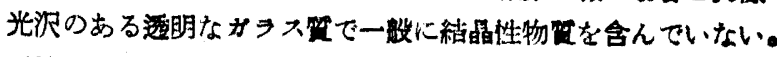

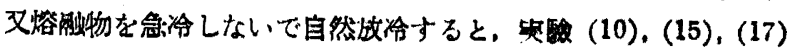

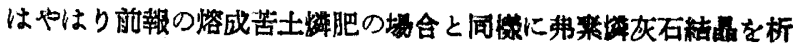
出し，外钼は光沢を失い，构溶特しく低下する。これに対し

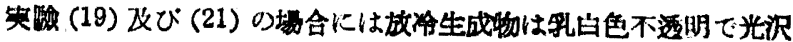
があつて，丁度カリ，石灰及び苦士，酸を主成分とするがラ火

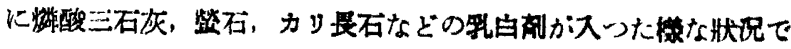

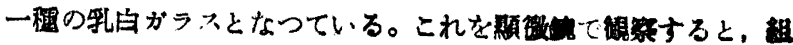

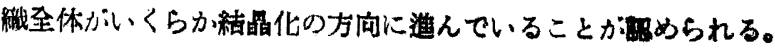

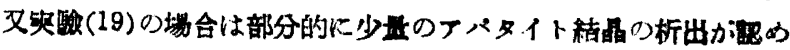

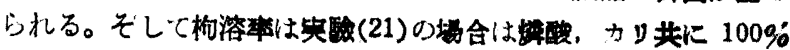

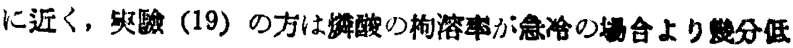

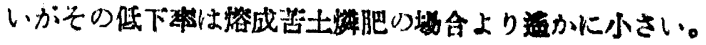

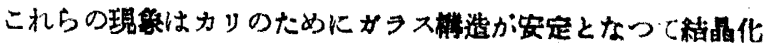

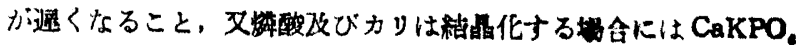
の梂なレナニフ燐肥型の生成物を作るためと思われる。邓この城 合にも弗策が存在すると、てパタイトを作って上进のがタ

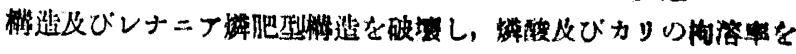


低下させる原因となる。実㯺(19)の場合は熔融溫度が高いため弗 素の大部分が $\mathrm{KF}, \mathrm{SiF}$ ‘)などの形で揮発して居り, 実驗(10)の 埸合には橴虽溫度が低く，時間す短いなどの原因で弗素の残留が 多いのと思われる。又実驗 (15)，(17) の場合沟榕率が低下し ているのはカリが少いためであろう。熔成カリ橉肥が急冷をしな

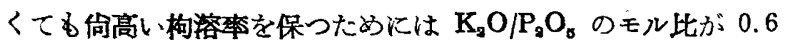
以上てあること、燐鉱石中の弗素が少いか, 又は多い場合は高溫 で充分脫弗することが必要條件である。

\section{4. 結 び}

䗲鉣石にカリ鉱石及びドロマイトなどを配合して愹成カリ耀肥 を作り，その鉣物組成及び枸溶宰などを詳細检討し，特に熔成性 肥中のカリの作用を中心として攻究した結果を要約すると垁の通 りである。

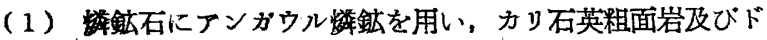
ロマイトの量を少なくし, 10:7:7 文は $10: 7: 10$ 程度にする 場合には比較的融点が高いか，これを充分高溫で熔融し，急泠し てがラス化すれば粼酸及びカり共に $95 \%$ 內外の枸溶率を示し， 枸溶磷酸 $14 \%$ 內外，构溶カリ $3 \%$ 內外を含むものか得られた。 一般に熔成䅉肥は実擥室で小規模に試製を行う場合には燐の揮発 耐火物の侵創熔入及び矮酸の生成などの割合が大きく，又念冷も それ程 万まく行かない。從つて工業的に良好な條件で大規模に行 ら场合には些驗室の結果よりも更に良い結果が得られると思われ る。

（2）橉銥石に対しカリ鉱を多く，ドロマイトを少くする場合

4) A. Messerschmitt, Angew. Chem. 51.197 208 (1938).
にはアルミナが多くなるなめ构溶率の高いものは得られないこと は既報第 1 報と同樣で充分論じ盡した結果と一致する。

（3）粼鉱石に対しゅり鉣攻びドロマイトを多く配合すると融 点は低下し，熔融物を急冷したものは $95 \%$ 內外の高い枸溶率を 得た。これを更に高溫度で充分熔融し，弗素の大部分を KF 又は $\mathrm{SiF}$ ななどの形で揮散させたものは急冷しないで，自然放冷しただ けです构溶率は殆んど低下しない。これはカリのために粼肥のガ ラス構造が保持され易いこと, 又粼酸及びカリは結晶化する場合 に可溶性の $\mathrm{CaKPO}_{4}\left[2 \mathrm{CaO} \cdot \mathrm{K}_{2} \mathrm{O} \cdot\left(\mathrm{P}_{2} \mathrm{O}_{6}\right)_{2}\right]$ の樣なレナ二ア耀肥 型の構造を取るためと考えられる。郎ち $\mathrm{P}_{2} \mathrm{O}_{5}$ に対し $\mathrm{K}_{2} \mathrm{O}$ を 0.6 或はそれ以上のモル比で用い, 粼鉱石として弗素の少いるのを用 いるか，又は弗素の多い場合は高溫で充分脫弗する場合には熔融 物は急冷する必要はなく，そのま末自然放冷しても构溶率の高い ものが得られる。

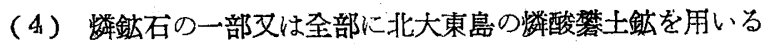
場合は，カリ鉣石から來るアルミナと共にアルミナの含有量が著 しく多くなつて构溶幾が低下するので，優良な愹成カリ橉肥は得 られない。

（5） カリ石英粗面岩の一部を鉄明楿石で置換すると：シリカ が少なく、酸化鉄が徒らに多くなつて生成物は充分がラス化させ 得ないし枸溶交は低くなる。

（6）ドロマイトの代りに石灰石を用いると飄点が幾らか高く なるが，枸溶率は大体同樣のものが得られる。（昭和 26 年 4 月， 日本化学会第 4 年会講演)

終にこの試驗研究には交部省科学試驗研究費に賲らところが多 く, ここに深謝の意を表したい

（東大農学部・東大理学部・盵料研究所）（昭和 26 年 7 月 25 日受理）

\title{
（5）北大東島燐鉱石を主要原料とする熔成燐肥の $\mathrm{X}$ 線䢙折法による研究
}

\author{
春日井新一郎・木村健二郎・高 橋 ‘浩・中川 正 男
}

終戰後輸入されている北大東島燐鉱石は鉄及びアルミニウム含 量力㥛めて高く，從つて過燐酸肥料の製造原料としては利用價值 を認め難いるのである。著者中の両名 (春日井・中川) は昭和 22 年の試驗に於て, 螾成苦土燐肥4) と同一製造理念に基いて同島粼 鉝石の耀酸枸溶化が可能であることを確かめ1)，さらに工業化試 酹を行うと共に原料配合を異にする11 種の試作品を得た2)。普通 燐鉣石中心燐酸は大陸性たると島嶼性たるとを問わず，一般に $\mathrm{Ca}_{10}(\mathrm{PO})_{0} \mathrm{~F}_{2}$ の形で存在することは, K.D. Jacob らがすでに明

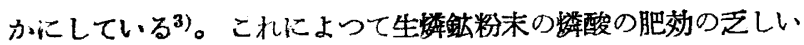
原因が明白になり, 製造を含めて粼酸問題研究に著しい進步が見

1）春日井新一郎, 中川正, 䗲酸肥料の製造法 特願 昭和 $23-342$.

2）山口敏博, 北大果䗲鉣石使用揢成橉肥工業試驗報告 昭和 25 年1月，日本特殊憐肥㙝会協議会に於て講演.

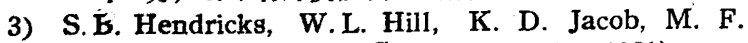
Jeff erson, Ind. Eng. Chem. 23, 1413 (1931).

4) 春日井新一郎, 小村輝男, 中川正男, 日本土壤肥料学雜誌 19, 178 (1949).
られたことは周知の通りである。また普通燐鉱石を原料とした熔 成晚肥が無晶形であることもすでに発表されている4)。今回，普 通粼鉣石とは化学組成を著しく異にする北大東島燐鉱石とのもの 及びこれを原料として製造した前記 11 種の哈成粼肥の燐酸の肥 効を栽培試驗によつて查定するとともに，これらに関連する諸物 質についてX線的研究を行つたので，その結果を報告する゙)。

\section{供試試料の原料配合割合，枸溶率及び肥効}

供試試料の原料配合割合は第 1 表に示してある。また第 2 表に 示すよ5にこれらの海酸の $2 \%$ クエン酸溶解性には大差が認めら れる。さらにこれらの熔成燐肥の裙酸の肥効を, 東京大学農学部に 於て常法に從い，大來及び水稻を供試作物として植木鉢試歌によ り過潾酸のそれと比較查定した。結果は第 2 表に一括した。なお 肥效本均指数は大麥文び水稳についてこれらの堌收率及び $\mathrm{P}_{2} \mathrm{O}_{0}$ 吸收笔指数の総本均值である。これによつて明かなようにNo. 11 及び No. 1 は過粼酸と大差ない肥効を示している。その他は過 燐酸に劣つている。要するに栽培試驗による肥效はある程度枸溶 